\title{
Organizacyjne i finansowe warunki wykonywania kolejowych przewozów aglomeracyjnych w Polsce z perspektywą potencjalnych usprawnień
}

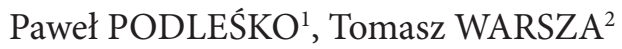

\begin{abstract}
Streszczenie
W artykule przedstawiono problematykę finansowania i organizacji kolejowych przewozów aglomeracyjnych. Wskazano w nim na problemy dotyczące tego segmentu, do jakich należy brak obowiązku ich organizacji i finansowania ze strony samorządowych struktur metropolitalnych. Opisano, dopuszczalne prawem dla jednostek samorządu terytorialnego, formy współpracy wertykalnej oraz określono słabości występujące w tym zakresie. Przywołano przykłady organizacji przewozów metropolitalnych w Polsce wykonywane mimo istniejących ograniczeń. Stwierdzono przy tym brak pełnego instrumentarium prawnego i finansowego, który zapewniałby metropoliom pewność prawną w organizacji przewozów aglomeracyjnych. Zaproponowano konkretne rozwiązania, przywołując informację o sposobie rozwiązania opisywanego problemu poza granicami Polski.
\end{abstract}

Słowa kluczowe: organizacja transportu publicznego, przewozy kolejowe, aglomeracje, integracja oferty, wspólny bilet

\section{Wstęp}

Jednym z oficjalnie deklarowanych przez Polskę celów rozwoju kolejowych przewozów pasażerskich jest (...) budowa systemów codziennego dojazdu, integrujacych ośrodki miejskie w układy aglomeracyjne i zwiększające zakres oddziaływania i obszarów funkcjonalnych miast oraz tworzacych powiazania sieciowe pomiędzy istniejącymi ośrodkami miejskimi w zagrożonych marginalizacja obszarach peryferyjnych, w tym poprawa przepustowości węzłów miejskich (...) [8, s. 75]. Wskazuje to na potrzebę opracowania warunków organizacyjnych, eksploatacyjnych i finansowych do stworzenia i wykonywania kategorii przewozów kolejowych powszechnie nazywanych „aglomeracyjnymi” [8, s. 31, s. 112].

W polskim systemie prawnym formalnie należałoby uznać, że przewozy aglomeracyjne są najbardziej zbliżone do metropolitalnych przewozów pasażerskich, które wyróżniono w art. 4 ust. 1 pkt 5a) [16] (dalej: ustawa PTZ). W rzeczywistości, przewozy aglomeracyjne funkcjonują na zasadach szczególnego rodzaju wojewódzkich przewozów pasażerskich. Obejmują bowiem przewóz osób wykonywany $\mathrm{w}$ granicach administracyjnych co najmniej dwóch powiatów i niewykraczający poza granice jednego województwa, z jednoczesnym zaangażowaniem fi- nansowym i organizacyjnym jednostek samorządu terytorialnego (JST) szczebla powiatowego, gminnego (a nawet wojewódzkiego). Metropolitalne przewozy pasażerskie, jest to przewóz osób publicznym transportem zbiorowym wykonywany $\mathrm{w}$ granicach związku metropolitalnego; inne niż gminne, powiatowe, powiatowo-gminne, wojewódzkie i międzywojewódzkie.

Celem artykułu jest zaprezentowanie zarówno obecnych, skomplikowanych ram organizacyjnych i finansowych wykonywania kolejowych pasażerskich przewozów uznawanych za aglomeracyjne, jak i zasadniczych warunków usprawnienia ich wykonywania. Jest to uzasadnione wynikami analiz demograficznych oraz specyfiką przewozów aglomeracyjnych, łączących cechy zarówno komunikacji miejskiej, jak i tradycyjnych pociągów osobowych.

\section{Istota problemu organizacji kolejowych przewozów aglomeracyjnych}

Obowiązek organizacji kolejowych przewozów pasażerskich został w Polsce nałożony wprost na dwa szczeble organizatorów publicznego transportu zbiorowego: ministra właściwego ds. transportu (przewozy

\footnotetext{
${ }^{1}$ Dr; Ministerstwo Funduszy i Polityki Regionalnej; e-mail: Pawel.Podlesko@mfipr.gov.pl.

${ }^{2}$ Mgr; Urząd Transportu Kolejowego; email: tomasz.warsza@gmail.com.
} 
międzynarodowe oraz przewozy międzywojewódzkie), a także marszałków województw (przewozy wojewódzkie). Jednocześnie ustawodawca zapewnił źródła finansowania przewozów wojewódzkich i międzywojewódzkich. W związku z nałożeniem na samorządy województw wymogu finansowania kolejowych przewozów regionalnych, w latach 2003-2009 zapewniono im na ten cel $1,5 \%$ udziału we wpływach $\mathrm{z}$ podatku CIT, natomiast od 2010 roku udział ten zwiększono o kolejne $0,75 \%$ i łącznie wynosi $2,25 \%$. Zgodnie $\mathrm{z}$ art. 3 [12], zwiększono poziom finansowania samorządów województw w zakresie transportu kolejowego o 0,75\% zwiększając łączny procent udziału samorządów województw w przychodach z tego źródła z 14\% do 14,75\%.

Pozostałe kategorie organizatorów, zarówno szczebla JST, jak i utworzone przez nie struktury (związek międzygminny, związek powiatów, związek powiatowo-gminny lub związek metropolitalny) nie mają obowiązku organizacji przewozów kolejowych.

Chociaż przepisy ustawy PTZ, art. 4 oraz art. 7 [16], nie wyłączają takiej możliwości, to jednak brak źródeł finansowania dla organizacji takich przewozów w sposób naturalny przekłada się na ograniczony charakter działalności gminnych, powiatowych i metropolitalnych organizatorów PTZ w dziedzinie transportu kolejowego. Organizator, jakim jest związek metropolitalny, naturalnie predestynowany do organizacji kolejowych przewozów pasażerskich, nie ma jednak prawnego (ustawowego) obowiązku zapewnienia swoim mieszkańcom dostępu do przewozów kolejowych, ponieważ nie ma ustawowego przymusu ich zapewnienia na swym obszarze.

Jednocześnie, należy przy tym nadmienić, że w procesie planowania rozwoju publicznego transportu zbiorowego na obszarze danego organizatora, konieczne jest uwzględnienie potrzeb zrównoważonego rozwoju publicznego transportu zbiorowego (art. 12 ust. 2 pkt 4 ustawy PTZ), ale to pojęcie jest dość ogólnie zdefiniowane w samej ustawie PTZ. Określono je bowiem, jako uwzględniające oczekiwania społeczne dotyczące zapewnienia powszechnej dostępności do usług publicznego transportu zbiorowego, zmierzające do wykorzystywania różnych środków transportu, a także promujące przyjazne dla środowiska i wyposażone $\mathrm{w}$ nowoczesne rozwiązania techniczne środki transportu, art. 4 pkt 1 ust. 28 [16]. Przy takim sformułowaniu, $w$ odniesieniu do przewozów na obszarach aglomeracji miejskich, można je odnosić przede wszystkim do wykonywania przewozów komunikacji miejskiej, ale rozumianych, jako transport publiczny realizowany z wykorzystaniem zróżnicowanego taboru (autobus, trolejbus, tramwaj, metro) pozostającego w gestii przedsiębiorstw transportu miejskiego funkcjonujących na obszarze działalności danego organizatora. Nie ujęto w nim natomiast potrzeby integracji oferty organizatorów różnego szczebla i różnych gałęzi transportu, jako celu, jakim powinien służyć zrównoważony rozwój publicznego transportu zbiorowego. Zasada wzajemnego uzgadniania linii komunikacyjnych przez sąsiednich organizatorów, art. 13 [16], jak również zasada uwzględniania zapisów planów transportowych wyższego rzędu, art. 11 [16] także są sformułowane na tyle ogólnie, że zachęcają do międzygałęziowej integracji oferty jedynie bardzo zgodnie współpracujących organizatorów.

Co prawda, w przypadku związku metropolitalnego wprowadzono obowiązek ustanowienia przez niego zintegrowanego systemu taryfowo-biletowego obowiązującego w jego granicach (art. 15a ustawy PTZ), ale nie miał on obowiązku organizacji przewozów kolejowych ${ }^{3}$. Oznacza to, że zdefiniowany w ustawie PTZ (art. 4 pkt 1 ust. 26) zintegrowany system taryfowo-biletowy oczywiście nie zakazuje włączenia przewozów transportem kolejowym w ofertę aglomeracyjną, ale też wprost tego nie nakazuje. Jest to rozwiązanie polegające na umożliwieniu wykorzystywania przez pasażera biletu, uprawniającego do korzystania $\mathrm{z}$ różnych środków transportu na obszarze właściwości organizatora publicznego transportu zbiorowego. Ponadto, ani ustawa PTZ, ani przepisy o transporcie kolejowym nie zawierają regulacji tworzących narzędzia, które pozwoliłyby efektywnie włączyć przewozy kolejowe do zintegrowanego systemu taryfowo-biletowego. Dlatego w praktyce, taki system może oznaczać głównie integrację ofert przewozów metrem, przewozów autobusowych, tramwajowych i trolejbusowych wykonywanych przez organizatorów różnego szczebla, tworzących dany związek.

Sytuację dodatkowo utrudnia skomplikowany system ulg ustawowych, obowiązujących odrębnie $\mathrm{i} w$ różnych wysokościach $\mathrm{w}$ transporcie kolejowym oraz w komunikacji miejskiej, w której ulgi są przyznawane i finansowane wyłącznie przez organizatorów samorządowych, na co nakłada się jeszcze zróżnicowanie wysokości ulg w zależności od kategorii pociągu [62]. W efekcie, system ulg $\mathrm{w}$ transporcie publicznym obejmuje ulgi ustawowe (refinansowane z budżetu państwa), tzw. ulgi samorządowe oraz ulgi handlowe, które wynikają z polityki handlowej każdego z przewoźników i są przez nich przyznawane dowolnie, na zasadach komercyjnych [40]. To z kolei rzutuje na zróżnicowane źródła rekompensowania przewoźnikom przychodów utraconych ze względu na stosowane ulgi.

\footnotetext{
${ }^{3}$ Zgodnie z artykułem 1 ust. 2 uchylonej [14], związek metropolitalny wciąż nie ma takiego obowiązku.
} 
Komplikacja tego systemu prowadzi do sytuacji, w której regulacja ulg w przejazdach środkami transportu publicznego ujęta jest w około 20 aktach prawa powszechnie obowiązującego (ustawy i rozporządzenia), nie licząc aktów prawa miejscowego [60]. Jednocześnie, obowiązujące przepisy wyłączają możliwość łączenia ulg ustawowych ze zniżkami handlowymi. Same ulgi ustawowe łączą w sobie zarówno charakter wyrównawczych świadczeń socjalnych (zniżki dla emerytów, osób niepełnosprawnych oraz studentów), jak i upustów dla osób wykonujących określone funkcje publiczne (np. dla funkcjonariuszy służb mundurowych w czasie wykonywania czynności służbowych) [29]. Dodatkowo, ze względu na odrębne „przypisywanie” ulg ustawowych do biletów nie tylko w poszczególnych rodzajach, ale wręcz w środkach publicznego transportu zbiorowego, a nawet $\mathrm{w}$ poszczególnych kategoriach pociągów, stosowanie wspólnych (np. w pociągach pospiesznych i komunikacji miejskiej) taryf i biletów jest utrudnione. Przepisy prawa powszechnie obowiązującego nie przewidują bezpośredniej rekompensaty kombinacji ustawowych i handlowych zniżek w przypadku, kiedy podróżny kupuje jeden bilet, lecz na różne środki transportu [33, s. 16]. Chociaż w polskim prawie istnieją formalne podstawy oferowania pasażerom możliwości nabywania jednego biletu na całą podróż, niezależnie od liczby, środków i rodzajów transportu wykorzystywanych w czasie jej trwania (art. 6 ust. 1) [15], to w praktyce inicjatywa w tym zakresie całkowicie zależy od zaradności organizatorów i operatorów publicznego transportu zbiorowego, bez żadnych finansowych zachęt do tworzenia tego typu systemowych rozwiązań. W efekcie, organizatorzy i operatorzy są wręcz karani za wdrażanie inicjatyw, ponieważ tracą przychody z ulg ustawowych $\mathrm{w}$ przypadku włączenia $\mathrm{w}$ proces integracji transportu kolejowego. Nie zyskują zaś z budżetu państwa niczego w zamian. Trudno przyjąć, aby w ten sposób realizowane były krajowe i unijne cele rozwojowe transportu publicznego.

Opisane aspekty wskazują, dlaczego przyjęte $\mathrm{w}$ ustawie PTZ rozwiązania systemowe mogą znaleźć bezpośrednie zastosowanie dla wyłącznie bardzo zgodnie współpracujących organizatorów pozostających na jednakowym szczeblu JST. Obecne przepisy wydają się pozostawać przy gałęziowym (a wręcz silosowym) postrzeganiu transportu publicznego, pozostawiając ewentualną harmonizację ofert różnych gałęzi transportu inicjatywie samych organizatorów. $Z$ jednej strony jest to $\mathrm{w}$ pewien sposób zrozumiałe, gdyż co do zasady trudno odgórnie zadekretować współpracę w dziedzinie ekonomicznej w jakimkolwiek obszarze. Z drugiej jednak strony, brak stabilnych, formalnych ram prawnych w praktyce uniemożliwia pełne włączenie transportu kolejowego w miejskie systemy przewozów pasażerskich i wpły- wa negatywnie na pewność prawną podejmowanych działań. Dla przewozów kolejowych, nazywanych powszechnie "aglomeracyjnymi”, włączenie nie tylko infrastrukturalne, ale głównie taryfowe, w miejski transport zbiorowy ma zasadnicze znaczenie. Wymaga to $\mathrm{z}$ kolei międzygałęziowego podejścia do rozumienia odpowiedzialności za ich rozwój.

\section{Stosowane w Polsce rozwiazania organizacyjne w zakresie kolejowych przewozów aglomeracyjnych}

Jak stwierdzono na wstępie, krajowe przepisy nie wyodrębniają takiej kategorii przewozów, jak kolejowe przewozy aglomeracyjne (metropolitalne). W literaturze przedmiotu istnieje jednak dość dużo definicji określających tę kategorię. W celu ich oznaczenia, np. anglosaska nauka (czasami zamiennie) posługuje się terminem "commuter rail” lub ,transit rail". Ten pierwszy termin oznacza zazwyczaj kolej obsługującą mieszkańców (commuters), [17, s. 244] podróźujących codziennie w celu nauki lub pracy z podmiejskich dzielnic danej aglomeracji, $\mathrm{z}$ sąsiednich aglomeracji oraz $\mathrm{z}$ obszarów funkcjonalnych aglomeracji do jej centrum [1, s. 16].

System kolejowy tego typu cechuje się m.in.: regularnością (równoodstępowością rozkładu jazdy) i wysoką częstotliwością kursowania pociągów w obszarze aglomeracyjnym, często wyodrębnioną funkcjonalnie infrastrukturą kolejową służącą obsłudze wyłącznie tych pociągów, przejazdami świadczonymi na podstawie biletów długookresowych, koncentracją na zapewnieniu pasażerom dotarcia do jednej lub dwóch głównych stacji zlokalizowanych w największych dzielnicach biznesowych aglomeracji, systemem opłat wyodrębnionym $\mathrm{z}$ dalekobieżnego ruchu pociągów, obsługą strefową stacji (tj. obsługiwaniem niektórych przystanków i stacji wyłącznie w określonych porach dnia i tygodnia). Operatorem „commuter rail” często bywa przewoźnik kolejowy wykonujący swoje zadania przewozowe również $\mathrm{w}$ innych obszarach regionu/kraju, traktując „commuter rail”, jako jeden z elementów swojej oferty. Przykładami mogą być: norweska Lokaltog Østlandet (kolej aglomeracyjna w Oslo) obsługująca Oslo i lotnisko Gardermoen wraz ze wschodnią częścią kraju, której operatorem jest norweski przewoźnik państwowy (Vygruppen) [64] lub system tzw. elektriczek, funkcjonujących m.in. na obszarze aglomeracyjnym Rygi i obsługiwanych przez łotewskiego przewoźnika państwowego [54].

Przykładami tak rozumianej „commuter rail”, często wskazywanymi w literaturze przedmiotu, są także niemieckie, austriackie lub duńskie systemy tzw. 
S-Bahn (Schnellbahn, Stadtbahn, Stadtschnellbahn) [24, s. 21]. Przypisanie S-Bahn do kategorii „,ommuter rail" wynika jednak przede wszystkim $\mathrm{z}$ aspektów infrastrukturalnych tego rodzaju przewozów kolejowych, a w mniejszym stopniu z posiadanych przez nie cech funkcjonalnych. W przypadku Berlina, S-Bahn, pozostając $\mathrm{w}$ ramach holdingu ogólnopaństwowego kolei niemieckich DB AG, jest częścią oferty Verkehrsverbund Berlin-Brandenburg (VBB), czyli zrzeszenia różnych przedsiębiorstw transportowych na obszarze krajów związkowych Berlina i Brandenburgii oraz miast Cottbus, Frankfurtu nad Odrą i Poczdamu. Pod względem powierzchni, VBB jest jedną z największych sieci transportowych w Europie. Na obszarze działania VBB ten sam bilet można wykorzystać w całym systemie transportu: S-Bahn, U-Bahn, tramwaju, autobusie, metrze i promie [56]. System S-Bahn stanowi w istocie włączenie biletowo-taryfowe odrębnego przewoźnika kolejowego w ofertę VBB.

"Transit rail" obejmuje przewozy zorganizowane na podobnych zasadach infrastrukturalnych, jak „commuter rail”, ale zazwyczaj jest to system operujący na krótszych dystansach w obrębie samych aglomeracji, z jeszcze wyższą częstotliwością kursowania. Obsługuje wszystkie kolejne przystanki na linii, przez to osiąga niższe prędkości handlowe, ale pociągami o wyższych przyspieszeniach i zapewniających szybszą wymianę pasażerów na przystankach $[28, \text { s. } 41]^{4}$. Generalnie jednak, tym co zdaje się odróżniać „transit rail", jest fakt organizacji przewozów kolejowych tego typu przez lokalnych (metropolitalnych) organizatorów transportu pasażerskiego, a także pełne włączenie ich $\mathrm{w}$ biletowy system aglomeracyjnego transportu publicznego, co nadaje mu cech „kolejowego metra”. Przykładem takich rozwiązań może być Transport for London, gdzie (z nielicznymi wyjątkami) taryfy miejskie obowiązują w przewozach kolejowych na terenie aglomeracji londyńskiej [61]. Podobna sytuacja ma miejsce również w Berlinie, dlatego informację o włączeniu S-Bahn do kategorii „commuter rail” opatrzono warunkowym komentarzem [39].

Pierwszy z opisywanych wariantów („commuter rail"), to tradycyjnie rozumiana regionalna kolej dojazdowa $\mathrm{z}$ własnym systemem taryf i opłat, zaspokajająca potrzeby przewozowe mieszkańców regionu, obszaru większego niż tylko sama aglomeracja. Stanowi rodzaj przewozów regionalnych wykonywanych z uwzględnieniem obsługi dużych miast. Aglomeracyjny charakter tego typu przewozów przejawia się przede wszystkim $\mathrm{w}$ aspektach: infrastrukturalnym (często wyodrębniona funkcjonalnie i własnościowo infrastruktura) oraz suprastrukturalnym (tabor przeznaczony do wykonywania opisanych przewozów). W Polsce, jako wręcz modelowy $\mathrm{w}$ takim przypadku, można wskazać przykład Warszawskiej Kolei Dojazdowej sp. z o.o. (WKD).

WKD należy do Samorządu Województwa Mazowieckiego, Miasta Stołecznego Warszawy oraz sześciu gmin leżących na jej trasie. Jednocześnie, jedynym zamawiającym i opłacającym przewozy jest Samorząd Województwa Mazowieckiego. Opisany przykład wskazuje, jak skomplikowana sytuacja występuje w Polsce w zakresie organizacji przewozów aglomeracyjnych. Wymaga bowiem włączenia w nie również organu odpowiedzialnego za przewozy szczebla regionalnego. Kolejnym przykładem może być PKP Szybka Kolej Miejska w Trójmieście sp. z o.o. (PKP SKM), zachowująca taryfy odrębne od miejskich, choć częściowo je honorująca. PKP SKM jest wspólną własnością PKP S.A., województwa pomorskiego, a także samorządów gminnych Gdańska, Sopotu, Gdyni, Pruszcza Gdańskiego i Rumii.

Drugi wariant („transit rail”), to kolej prawdziwie aglomeracyjna, włączona zarówno infrastrukturalnie, taryfowo, jak i zintegrowana biletowo $\mathrm{z}$ systemem miejskiego (aglomeracyjnego) transportu publicznego. W takim systemie, uciążliwość przesiadek jest złagodzona funkcjonowaniem jednolitego aglomeracyjnego systemu transportowego, w pełni obejmującego również przewozy kolejowe świadczone przez aglomeracyjnego organizatora i umożliwiającego dowolną zmianę środków transportu, bez konieczności ponoszenia dodatkowych opłat, czy bez konieczności znajomości (skomplikowanych zazwyczaj) taryf i ofert przewoźników kolejowych. W takim ujęciu, aglomeracyjny charakter wynika nie tylko $\mathrm{z}$ aspektów infrastrukturalnego i suprastrukturalnego, ale również $\mathrm{z}$ aspektu organizacyjnego, oznaczającego realizację przewozów na potrzeby miejskiego (aglomeracyjnego) organizatora transportu publicznego i włączenie ich w aglomeracyjny system taryfowo - biletowy. Jako polski przykład można przywołać warszawską Szybką Kolej Miejską sp. z o.o. (SKM Warszawa).

$\mathrm{Na}$ polskim gruncie również podejmowano problematykę definiowania kolejowych przewozów aglomeracyjnych. Powołując się na opracowania międzynarodowych organizacji działajacych $\mathrm{w}$ obszarze transportu kolejowego, w polskich opracowaniach wskazywano nie tylko na cechy funkcjonalne przewozów aglomeracyjnych, ale też na zasięg odbywanych podróży (w ujęciu czasowym i przestrzennym), wysoką częstotliwość kursowania, czy niewielkie odległości

\footnotetext{
${ }^{4}$ Szczegółowe informacje na temat charakterystyki eksploatacyjnej i funkcjonalności taboru szynowego przeznaczonego do wykonywania tego typu połączeń są przedmiotem odrębnych analiz [26].
} 
między przystankami [30, s. 37], [25, s. 172]. Zgodnie $\mathrm{z}$ terminologią stosowaną $\mathrm{w}$ oficjalnej statystyce publicznej przez regulatora rynku kolejowego w Polsce (Prezesa Urzędu Transportu Kolejowego - dalej: Prezesa UTK), przewozy aglomeracyjne to (...) przewozy, które maja na celu zaspokajanie potrzeb transportowych dużego ośrodka miejskiego / konurbacji / obszaru metropolitalnego, jak również potrzeb transportowych pomiędzy takim ośrodkiem i sąsiednimi obszarami; częstotliwość pociagów aglomeracyjnych jest wysoka (zazwyczaj co najmniej 4 pociagi na godzinę), odległość pomiędzy przystankami jest relatywnie niewiel$k a$, a siatka połaczeń jest silnie powiazana $z$ siatka połączeń innych środków transportu zbiorowego; pociagi sa przystosowane do przewozu dużej liczby pasażerów i umożliwiaja sprawna ich wymianę, $w$ odróżnieniu od przewozów regionalnych, które maja na celu zaspokajanie potrzeb transportowych całego regionu (...) [30, s. 37]. Z przytoczonej definicji wynika, że w polskiej terminologii również wyodrębnia się kompleksowo zintegrowane $\mathrm{z}$ miejskim transportem aglomeracyjnym „transit rail" od tradycyjnie rozumianych „commuter rail”.

Bazując na międzynarodowych doświadczeniach z przewozami aglomeracyjnymi, uwzględniając krajowe uwarunkowania w tym zakresie oraz doprecyzowując określenie stosowane przez Prezesa UTK ${ }^{5}$, można sformułować następującą definicję kolejowych przewozów aglomeracyjnych: (...) jest to system infrastruktury kolejowej, przypisanego do niej parku taboru kolejowego, punktów odprawy pasażerów (dworców i przystanków) oraz sposób organizacji przewozów w obszarze aglomeracji miejskich $i$ ich obszarów funkcjonalnych, charakteryzujący się wysoka częstotliwością obsługi linii, częstymi zatrzymaniami pociagów na gęstej sieci przystanków, kursowaniem pociagów w stałym takcie, a także włączeniem przewozów w miejski (aglomeracyjny) system biletowy (...). Tytułem uzupełnienia należy nadmienić, że warunkiem prawidłowego funkcjonowania kolejowych przewozów aglomeracyjnych jest wyposażenie wybranych punktów zatrzymań pociągów (zazwyczaj poza ścisłym centrum aglomeracji) w parkingi typu park and ride, zapobiegające wlewaniu się potoków samochodów osobowych do środka aglomeracji oraz umożliwiające ich przejęcie przez transport masowy, jakim jest transport kolejowy [57].

Definiowanie przewozów aglomeracyjnych $\mathrm{z}$ wykorzystaniem maksymalnej odległości wykonywanych przewozów oraz czasów podróży (często okre- ślane, jako podróże na odcinki nie dłuższe niż $15 \mathrm{~km}$ i trwające nie dłużej niż $30 \mathrm{~min}$ ) [20, s. 17], wydają się mieć w tym wypadku mniejsze znaczenie. Wynika to bowiem z globalnego trendu polegającego na suburbanizacji oraz rozlewaniu się (zazwyczaj w sposób niekontrolowany) dużych miast. W efekcie sprawia to, że nawet dłuższe niż 30 minutowe czasy przejazdu mogą się odbywać w obrębie wciąż tego samego miasta. Przykładowo, przejazd na trasie London Kings Cross - Hayes\&Harlington trwa około 55 minut, ale odbywa się wciąż w granicach Londynu i na zasadach taryfy obowiązującej w tym mieście [51]. Z tego powodu, bardziej miarodajnym wskaźnikiem ,aglomeracyjności" kolejowych przewozów pasażerskich wydaje się być czytelna rytmiczność, zachowana cykliczność i równoodstępowość kursowania pociągów, które powodują, że przejmują one funkcje komunikacji miejskiej - zwłaszcza ze względu na ich włączenie w aglomeracyjny system taryfowo-biletowy. To sprawia, że w przewozach aglomeracyjnych, pociągi w poszczególnych relacjach kursują nawet w cyklu (taktach, odstępach) co kilka minut, dostosowanym do migracji wahadłowej i natężenia ruchu $\mathrm{w}$ godzinach szczytu [34].

W Polsce, aglomeracje to tereny wokół miast wojewódzkich [32, s. 173-175]. Pierwotnie, obszary takie zostały wyodrębnione w Koncepcji Przestrzennego Zagospodarowania Kraju 2030 [9]. KPZK. W dokumencie tym m.in.: przedstawiono wizję zagospodarowania przestrzennego kraju do 2030 roku, określono cele i kierunki polityki przestrzennego zagospodarowania kraju, wskazano zasady, według których działalność człowieka powinna być realizowana w przestrzeni. Obszary aglomeracyjne zdefiniowano jako: (...) obszar kraju wyodrębniony na podstawie wspólnych cech geograficznych i silnych wewnętrznych powiazań. Przykładem obszaru funkcjonalnego może być duże miasto i otaczające je gminy. Mieszkańcy tych gmin na co dzień dojeżdzaja do pracy w mieście, ucza się w nim, studiują, chodza do teatru. Oznacza to, że taki obszar posiada wspólny potencjał $i$ bariery rozwojowe, niezależne od granic administracyjnych (...) [49].

$\mathrm{Na}$ takiej podstawie zaliczono do nich następujące obszary: Warszawę oraz Aglomerację Górnośląską (Katowice wraz z miastami wchodzacymi w skład Górnośląskiego Związku Metropolitalnego), Łódź, Kraków, Trójmiasto (Gdańsk - Sopot - Gdynia z głównym ośrodkiem miejskim w Gdańsku), Wrocław, Po-

\footnotetext{
${ }^{5}$ Terminologia stosowana w sprawozdawczości systematyzowanej przez Prezesa UTK ma szczególny charakter, ponieważ jest terminologią branżową, pozwalającą podmiotom zobowiązanym (w tym przypadku przewoźnikom kolejowym) na relatywnie szybkie zidentyfikowanie oraz przypisanie swojej działalności do określonej kategorii, wyróżnionej na potrzeby statystyczne. Stąd, w artykule zaproponowano definicję rozszerzoną, uwzględniającą również aspekty organizacyjne przewozów.
} 
znań, Szczecin, kształtujący się duopol Bydgoszcz - Toruń, Lublin oraz miasta wojewódzkie o znaczeniu krajowym, w których następuje systematyczna koncentracja funkcji metropolitalnych o znaczeniu międzynarodowym i krajowym: Białystok i Rzeszów, Opole, Olsztyn, Kielce, Gorzów Wielkopolski i Zielona Góra [49, s. 37]. Z kolei, zgodnie z klasyfikacją unijnego programu ESPON, opracowaną w 2004 r., spośród 76 tzw. obszarów MEGA (Metropolitan European Growth Areas) występujących w Europie, w Polsce zidentyfikowano jeden potencjalny obszar tego typu tzw. Potential MEGA (Warszawa) oraz siedem ośrodków słabo wykazujących funkcje metropolitalnych obszarów wzrostu tzw. Weak MEGA (Gdańsk-Gdynia, Kraków, Katowice, Poznań, Wrocław, Szczecin, Łódź) [23, s. 81-86]. Szczegółowy zasięg tych obszarów ilustruje mapa, której ze względu na ograniczenia redakcyjne nie zamieszczono, por. [49].

Obecnie, zgodnie z Umową Partnerstwa, najważniejsze ośrodki miejskie w kraju to tereny miast wojewódzkich i ich obszarów funkcjonalnych [47], które z kolei są szczegółowo delimitowane w poszczególnych kontraktach wojewódzkich zawieranych przez Radę Ministrów z każdym z województw [3, s. 177]. Umowa Partnerstwa jest formą kontraktu między poszczególnym państwem członkowskim UE, a samą Unią Europejską (działającą w jej imieniu Komisją Europejską), w którym określono kierunki interwencji w latach 2014-2020 dla trzech polityk unijnych: Polityki Spójności, Wspólnej Polityki Rolnej i Wspólnej Polityki Rybołówstwa w taki sposób, aby przyczyniały się one do realizacji unijnej strategii zwanej EUROPA2020 w każdym z państw [45].

W Polsce, szczególnie intensywne procesy rozwoju metropolii widoczne są między innymi na obszarach wokół Warszawy, Krakowa, Trójmiasta, Poznania, Lublina i Wrocławia [27, s. 221] oraz [22] $]^{6}$ Procesom demograficznym i urbanizacyjnym nie towarzyszy jednak rozwój instytucjonalnych form wsparcia kolejowych przewozów aglomeracyjnych ${ }^{7}$. Istotnym problemem, nakładającym się na brak dostępności finansowania i organizacji przewozów aglomeracyjnych jest ograniczony katalog form prawnych przeznaczonych dla organizatorów i operatorów różnych szczebli, którzy wspólnie chcą świadczyć przewozy kolejowe zintegrowane $\mathrm{z}$ pozostałymi usługami przewozowymi w publicznym transporcie zbiorowym na terenach aglomeracji. W tym zakresie, JST są związane przepisami prawa, które dopuszczają nastę- pujące możliwości: wewnętrzna jednostka organizacyjna, odrębna jednostka budżetowa utworzona przez organizatora, spółka kapitałowa (w tym spółka komunalna), stowarzyszenie oraz związek JST ${ }^{8}$. Rozwiązanie polegające na stworzeniu w danym urzędzie jednostki wewnętrznej lub odrębnej jednostki budżetowej, która miałaby obsługiwać wszystkie pozostałe JST różnych szczebli, wchodzące w skład aglomeracji jest prawnie niedopuszczalne.

Zgodnie z art. 15 ust. 1 [16], do zadań organizatora należy w szczególności zapewnienie odpowiednich warunków funkcjonowania publicznego transportu zbiorowego. Wynika z tego, iż dla poszczególnych JST organizacja PTZ jest zadaniem własnym danego samorządu. Co prawda, zgodnie z przepisami o samorządzie gminnym, wykonywanie zadań publicznych przez gminy może następować $\mathrm{w}$ drodze współdziałania $\mathrm{z}$ innymi jednostkami samorządu terytorialnego. Ponadto gminy, związki międzygminne oraz stowarzyszenia JST mogą sobie wzajemnie udzielać pomocy, w tym pomocy finansowej. Nie ma natomiast możliwości prawnej całkowitego przekazania przez JST własnych zadań do realizacji innym JST - wyższego szczebla.

Z kolei spółki kapitałowe są programowo ukierunkowane na realizację celów gospodarczych wspólników lub udziałowców, a nie na zaspakajanie zbiorowych potrzeb mieszkańców danej JST [31]. Nie wyklucza to oczywiście możliwości tworzenia spółek kapitałowych z udziałem różnych szczebli JST w celu organizacji transportu publicznego. Należy jednak pamiętać, że spółka jest podmiotem odrębnym od swoich twórców zarówno w stosunkach cywilnych, jak i administracyjnych. Spółka występuje w obrocie we własnym imieniu, ma własne organy, a za zaciągnięte zobowiązania odpowiada swoim własnym majątkiem. Relacje pomiędzy JST i utworzoną spółką opierają się na przesłankach cywilnoprawnych. Zatem zarówno JST, jak i spółka zachowują autonomię.

Przepisy o gospodarce komunalnej odmiennie kształtują kwestię istnienia rady nadzorczej i stanowią, iż „w spółkach z udziałem jednostek samorządu terytorialnego działa rada nadzorcza”. Pozostałe przepisy kodeksu spółek handlowych o funkcjonowaniu spółek stosuje się odpowiednio do spółki z udziałem jednostek samorządu terytorialnego. W ocenie Najwyższej Izby Kontroli (NIK): (...) Wykonywanie zadań publicznych jednostek samorządu terytorialnego za pośrednictwem tworzonych przez nie spółek, w pod-

\footnotetext{
${ }^{6}$ Stąd do dalszych analiz przyjęto jako grupę reprezentatywną: Poznań, Warszawę i Kraków.

${ }^{7}$ Powstanie związku metropolitalnego wymaga przyjęcia ustawy przeznaczonej dla określonego związku [10]. Poza tym, samo tworzenie i funkcjonowanie związków metropolitalnych nie jest prawnie szczegółowo uregulowane.

${ }^{8}$ Zgodnie $\mathrm{z}$ art. 7 [13], JST nie są uprawnione do tworzenia przedsiębiorstw państwowych.
} 
danych kontroli gminach i województwach, zdaniem NIK, obarczone było wieloma nieprawidłowościami takimi jak: podejmowanie przedsięwzięć bez rzetelnego ich przygotowania (brak analiz ekonomicznych, brak oszacowania niezbędnych środków, nieuwzględnianie występujacego ryzyka), niezapewnienie profesjonalnego i skutecznego wykonania zadań, a także gospodarowanie majatkiem niezgodnie z celami statutowymi. W toku kontroli stwierdzono także przypadki niezapewnienia warunków organizacyjnych i finansowych realizacji powierzonych zadań oraz braku dbałości o zmniejszanie kosztów prowadzonej działalności, a tym samym kosztów realizacji zadań publicznych. Wykonywanie zadań samorządu terytorialnego przez spółki poszerzało organizacyjne i finansowe możliwości ich realizacji, jednak nieprawidłowości $w$ działaniach spótek negatywnie rzutowały na skuteczność i efektywność tych działań. W ocenie Najwyższej Izby Kontroli, realizacja zadań publicznych przez skontrolowane samorządy gmin $i$ województw za pośrednictwem tworzonych przez nie spółek nie była efektywna. Nieprawidłowości, zarówno przy tworzeniu spółek, jak i w gospodarowaniu przez nie majatkiem, a także $w$ wykonywaniu przez spółki poszczególnych zadań, wpłynęły na obniżenie skuteczności realizacji zadań samorza$d u$. Ponadto, $w$ toku kontroli stwierdzono przypadki braku podstawy prawnej do prowadzenia przez niektóre spótki działalności w poszczególnych obszarach (...) $[4$, s. 6].

Korzystanie przez JST, w obrocie prawnym i gospodarczym ze spółek, wymaga zaangażowania profesjonalnej kadry pracowników doświadczonych w wykorzystywaniu na rynku z przepisów handlowych dotyczących tej formy działalności. Tymczasem, ani JST nie mają ku temu odpowiednich zasobów, ani też organizacja przewozów aglomeracyjnych nie jest działalnością rynkową, nastawioną na zysk. Biorąc pod uwage ustalenia NIK z cytowanej kontroli, JST brakuje pewności prawnej w zakresie dopuszczalności wykorzystywania form spółek kapitałowych w działalności o charakterze użyteczności publicznej. Odnosząc się zaś do formuły stowarzyszenia należy zaznaczyć, że jest jedyną dopuszczalną dla JST strukturą o celach niezarobkowych, pozwalającą na członkostwo w niej JST każdego szczebla oraz różnych obszarów. Zasadniczym mankamentem stowarzyszenia jest jednak brak możliwości przekazania uprawnień organizatorów transportu publicznego należnych przystępującym do niego JST. Jeśli natomiast chodzi o związki JST, to jak już wyjaśniono, żaden z jego wariantów (związki gmin, związki powiatów, związki powiato- wo-gminne, związki aglomeracyjne) nie ma obowiązku organizowania kolejowych przewozów pasażerskich. Co więcej, działalność transportowa związków JST jest jedną z wielu, które te struktury mogą prowadzić. Nie są to zatem wyspecjalizowane formy prawne przeznaczone do zarządzania skomplikowaną materią publicznego transportu zbiorowego.

Wskutek braku w Polsce instytucjonalnych, finansowych oraz prawnych form i struktur przeznaczonych do wspierania rozwoju kolejowych przewozów aglomeracyjnych, organizatorzy PTZ różnych szczebli JST zmuszeni są poszukiwać dostępnych im rozwiązań, doraźnie eliminujących występujące ograniczenia systemowe. Poza przywołanym już przykładem WKD, można wskazać na Poznańską Kolej Metropolitalną (PKM). Jest to projekt polegający na uruchomieniu przez Koleje Wielkopolskie sp. z o.o. (KW) przewozów pasażerskich obsługujących aglomerację Poznania na ogólnodostępnej infrastrukturze kolejowej zarządzanej przez PKP PLK S.A. Pierwsze pięć linii PKM połączyło Grodzisk Wielkopolski, Jarocin, Nowy Tomyśl, Wągrowiec i Swarzędz z Poznaniem. Docelowo, w Poznaniu pociągi uruchamiane w ramach projektu PKM będą zatrzymywać się na około 60 stacjach i przystankach. Już obecnie, kursy w godzinach szczytu odbywają się nawet co 30 minut [53]. Projekt jest wspólnym przedsięwzięciem Samorządu Województwa Wielkopolskiego, Miasta Poznania, Powiatu Poznańskiego, Stowarzyszenia Metropolia Poznań oraz 40 gmin i 10 powiatów Wielkopolski. PKM obejmuje swoim zasięgiem obszar $\mathrm{w}$ promieniu około $50 \mathrm{~km}$ od Poznania [58]. Marszałek Województwa Wielkopolskiego, jako organizator regionalnych kolejowych przewozów pasażerskich na terenie Wielkopolski, przystąpił do projektu PKM, wraz z jednym ze swoich operatorów - KW $\mathbf{W}^{9}$. Jest to przewoźnik, który co do zasady wykonuje przewozy o charakterze regionalnym, zgodnie z przepisami PTZ.

PKM działa na zasadzie solidaryzmu JST $\mathrm{w}$ nim uczestniczących, który w praktyce obejmuje współfinansowanie przez nie zatrzymań na swoim obszarze pociągów regionalnych, uruchamianych przez Marszałka. Polega to na tym, że wszystkie samorządy położone wzdłuż danej linii kolejowej przekazują określoną dotację celową Samorządowi Województwa Wielkopolskiego na pokrywanie części kosztów uruchamianych połączeń kolejowych [21]. Włączenie pociągów $\mathrm{KW}$ w komunikację miejską polega na honorowaniu w nich, w obrębie tzw. strefy kolejowej A (tj.: wszystkich stacji z nazwą Poznań oraz stacja Kiekrz) biletów okresowych, sieciowych ze strefą

\footnotetext{
${ }^{9}$ Należy podkreślić, że na terenie Wielkopolski przewozy regionalne organizowane przez Marszałka wykonuje również POLREGIO sp. z o.o. [52].
} 
A Zarządu Transportu Miejskiego w Poznaniu zakodowanych na Poznańskiej Elektronicznej Karcie Aglomeracyjnej (PEKA), Elektronicznej Legitymacji Studenckiej (ELS) lub doktoranckiej (ELD) [43]. Ponadto, w KW dostępna jest m.in. oferta pn.: BusTramwaj-Kolej (BTK). Jest to kolejowy bilet miesięczny (ważny w tzw. strefach A-G na terenie Wielkopolski), który obowiązuje w pociągach osobowych KW i POLREGIO oraz w środkach komunikacji miejskiej organizowanej przez Zarząd Transportu Miejskiego w Poznaniu. Podróżni korzystający z komunikacji autobusowej w Gnieźnie mogą łączyć bilet BTK - Strefa F z ofertą MPK sp. z o.o. w Gnieźnie [44]. Szczegółowe informacje, wraz z granicami stref, zaprezentowano na rysunku 1.

PKM działa, jako wyróżniony wcześniej, typ „kolei regionalnej" "'commuter rail", opartej na prezentowa- nej formule stowarzyszenia gminno-powiatowego, ale z udziałem Marszałka, który wykonując swoje ustawowe zadania organizatora szczebla regionalnego, dopuszczając wzajemne honorowanie części biletów, dodatkowo zapewnia obsługę szczególnych, lokalnych potrzeb aglomeracji poznańskiej ${ }^{10}$. Formalnie jednak, PKM to oferta handlowa kolejowego przewoźnika regionalnego, utworzonego do wykonywania zadań przewozowych o innym charakterze. Polega na wzajemnym honorowaniu części biletów, co nie sprzyja uproszczeniu oferty kolejowej, ani oferty w komunikacji miejskiej i nie ułatwia uczynienia ich bardziej zrozumiałymi dla pasażerów. W żaden sposób nie umniejsza to roli PKM wręcz przeciwnie: wskazuje na determinację wielkopolskich JST, które umiejętnie wykorzystują dostępne im formy prawne do stworzenia, satysfakcjonującej mieszkańców, oferty transportu publicznego.

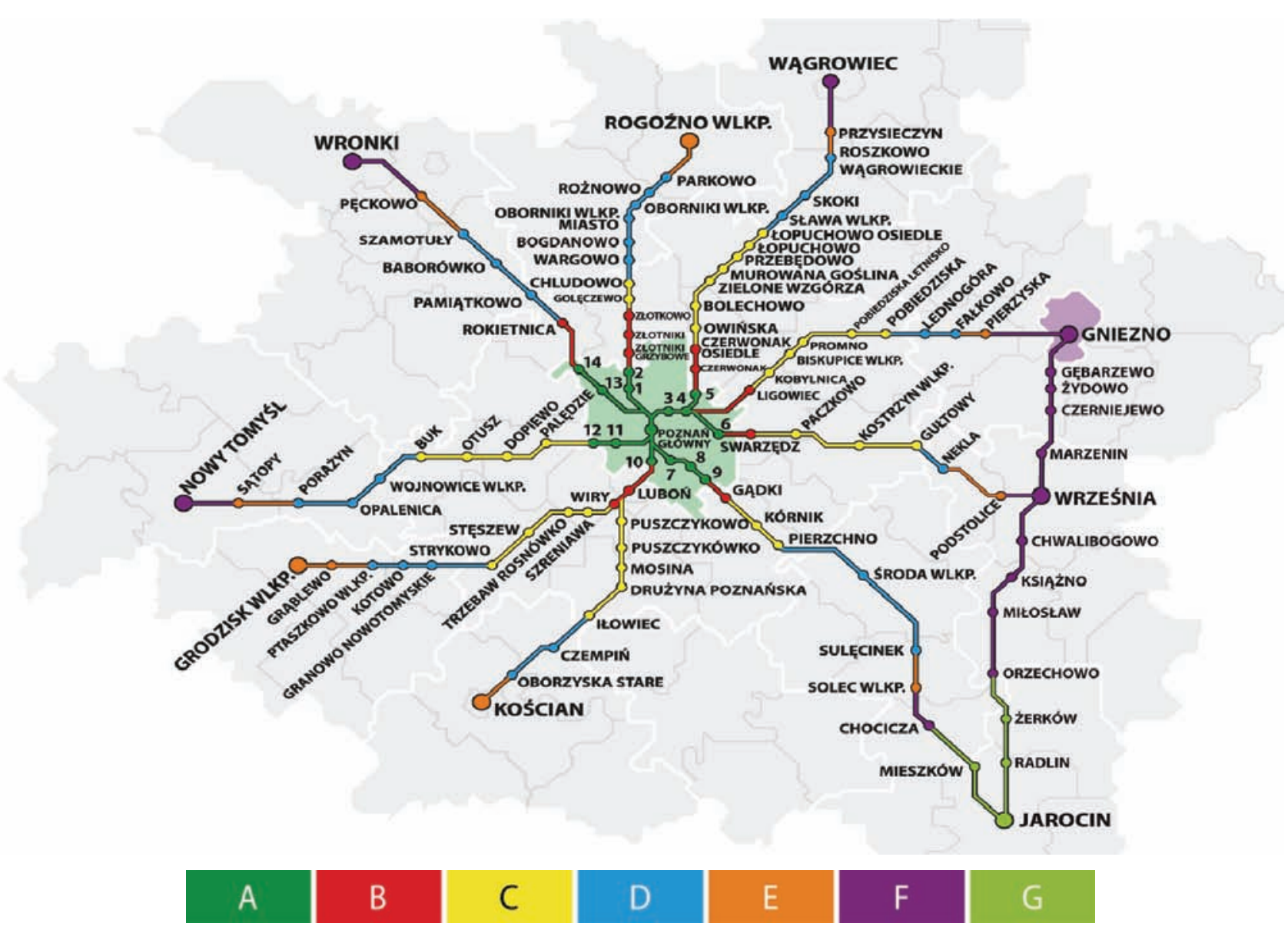

Rys. 1. Granice stref biletowych BTK na liniach kolejowych [35]

\footnotetext{
${ }^{10}$ Należy wyjaśnić, że obszar działalności Stowarzyszenia Metropolia Poznań, poza transportem, obejmuje również: kulturę, ochronę środowiska, sport, edukację, sprawy rodziny, seniorów, zdrowia i gospodarki [59].
} 
Szybka Kolei Aglomeracyjna w Krakowie (SKA) to kolejny przykład oferty handlowej. Wykorzystuje ona pociągi uruchamiane przez Koleje Małopolskie sp. z o.o. (Koleje Małopolskie). Jest to system połączeń kolejowych obejmujących docelowo Kraków i północną część województwa małopolskiego na ogólnodostępnej infrastrukturze kolejowej zarządzanej przez PKP PLK S.A. Obecnie, już trzy uruchomione linie SKA połączyły Kraków Główny z: Krakowem Lotniskiem, Wieliczką Rynkiem - Kopalnią, Sędziszowem, Podborami Skawińskimi, Trzebinią oraz Tarnowem. Pociągi uruchamiane w ramach projektu SKA zatrzymują się na 50 stacjach i przystankach. Kursy w godzinach szczytu na kluczowych odcinkach, odbywają się co 30 minut.

Projekt jest przedsięwzięciem Samorządu Województwa Małopolskiego i Krakowa, w którym partycypują samorządy gminne i powiatowe położone na trasach SKA. Poszczególne gminy i powiaty uczestniczą w projekcie przez swój wkład w projekty infrastrukturalne dotyczące dworców, przystanków kolejowych i infrastruktury towarzyszącej [18, 19, 37, 38]. Analogicznie, jak w przypadku PKM, do projektu krakowskiego systemu aglomeracyjnego, musiał przystąpić Marszałek Województwa Małopolskiego jako organizator regionalnych kolejowych przewozów pasażerskich na terenie Małopolski, wraz z jednym z operatorów uruchamiających zamawiane przez niego pociągi [38 ${ }^{11}$. Kluczowym elementem SKA jest jednak jej integracja taryfowa $\mathrm{z}$ transportem miejskim. $\mathrm{Na}$ terenie przebiegu SKA obowiązuje m.in. Małopolska Karta Aglomeracyjna (MKA), która stanowi narzędzie oferujące pasażerom wygodny dostęp do rozbudowanej oferty biletowej organizatorów i operatorów PTZ w województwie. Poza biletami na pociągi organizowane przez Województwo Małopolskie, system MKA oferuje także dostęp do biletów komunikacji miejskiej w takich miastach, jak: Kraków, Tarnów, Nowy Targ, Zakopane i Wieliczka. W ramach systemu MKA, funkcjonują dwa nowoczesne nośniki - plastikowa karta zbliżeniowa (nośnik biletów okresowych) oraz bezpłatna aplikacja mobilna iMKA (nośnik biletów jednorazowych i okresowych). Na trasie Wieliczka Rynek Kopalnia - Kraków Główny oraz Wieliczka Rynek Kopalnia - Kraków Olszanica (na odcinku od 1 do $20 \mathrm{~km}$ ) poza klasycznymi biletami obowiązuje bilet zintegrowany (również zintegrowany miesięczny) ważny na pociągi i komunikację miejską na terenie Gminy Kraków. Do przystanku kolejowego Wieliczka Rynek Kopalnia, obsługiwanego przez Gminę Kraków, można dojechać Autobusowymi Liniami
Dojazdowymi, w których na przejazd miejską komunikacją autobusową i pociągiem można zakupić jeden bilet. Koleje Małopolskie honorują większość biletów wystawianych przez spółkę POLREGIO na zasadzie wzajemności. Na odcinkach Kraków Główny - Kraków Bronowice oraz na odcinku Nowy Targ - Zakopane honorowane są bilety również na zasadzie wzajemności Kolei Małopolskich i Kolei Śląskich [42].

Nie zmienia to jednak faktu, że pod szyldem SKA również uruchomiono ofertę handlową regionalnego przewoźnika kolejowego. Został mu dodany kolejny segment przewozów do obsługi, określany mianem aglomeracyjnych. W efekcie, Koleje Małopolskie wyposażono $\mathrm{w}$ zróżnicowany park taborowy (zarówno do przewozów regionalnych, jak i aglomeracyjnych), co niewątpliwie generuje wyższe koszty jego utrzymania. SKA to również przykład „commuter rail”, czyli przewoźnika regionalnego obsługującego metropolię. Przewoźnik zachowuje własny system taryfowo-biletowy, a dodatkowo włącza się w system biletowy poszczególnych terenów aglomeracji krakowskiej. Nie zmienia to oczywiście faktu, że taka obsługa jest konieczna dla Krakowa. Charakterystyka topografii tego miasta opiera się m.in. na jego średniowiecznej zabudowie, której możliwości przebudowy na potrzeby ruchu drogowego są mocno ograniczone. Rozwój masowych przewozów kolejowych stanowi zatem pożądaną alternatywę.

SKM Warszawa jest samorządowym przewoźnikiem kolejowym należącym do m.st. Warszawy stanowiąc funkcjonalnie i taryfowo element Warszawskiego Transportu Publicznego. SKM Warszawa jest jedynym $\mathrm{w}$ Polsce przykładem normalnotorowego przewoźnika kolejowego będącego własnością samorządu miejskiego i regularnie (rozkładowo) obsługującego metropolię. SKM Warszawa świadczy usługi transportu pasażerskiego $\mathrm{w}$ ramach aglomeracji warszawskiej, na istniejących liniach zarządzanych przez PKP Polskie Linie Kolejowe SA. Pierwsze połączenie kolejowe - linia S1, uruchomiono w 2005 roku, na trasie Warszawa Zachodnia - Warszawa Falenica. Obecnie, SKM Warszawa przewozi pasażerów na czterech trasach, o długości około $160 \mathrm{~km}$, obsługując 53 stacje i przystanki na terenie aglomeracji warszawskiej. Częstotliwość połączeń, w zależności od linii SKM Warszawa, jest zróżnicowana i waha się od około 30 do 60 minut, przy czym na części linii odjazdy nie zachowują równoodstępowości.

W związku z powiązaniem właścicielskim, SKM Warszawa jest $\mathrm{w}$ pełni zintegrowana $\mathrm{z}$ taryfą biletową transportu miejskiego na terenie aglomeracji

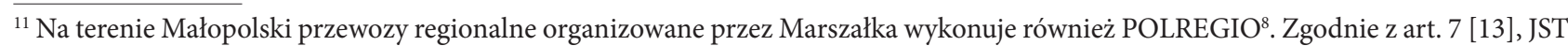
nie są uprawnione do tworzenia przedsiębiorstw państwowych.
} 
warszawskiej: w pociągach obowiązują bilety warszawskiego Zarządu Transportu Miejskiego (ZTM), a pasażer na podstawie tego samego, dowolnego biletu (jednorazowy, długoookresowy) może, poza pociągami SKM Warszawa, odbywać podróż również pozostałymi środkami transportu uruchomionymi przez ZTM (autobus, tramwaj, metro) ${ }^{12}$. Obecnie, finansowanie usług przewozowych organizowanych przez ZTM (w tym realizowanych przez SKM Warszawa) odbywa się ze środków pochodzących z dwóch podstawowych źródeł: budżetu miasta, w tym przychodów ze sprzedaży biletów oraz dotacji z gmin, z którymi obowiązują umowy dot. organizacji przewozów w publicznym transporcie zbiorowym [5].

W zakresie finansowania transportu publicznego Miasto Stołeczne Warszawa wypracowało praktykę podpisywania $\mathrm{z}$ samorządami podwarszawskich gmin indywidualnych porozumień administracyjnych dotyczących wspólnego wykonywania zadań w zakresie lokalnego transportu zbiorowego. Współpraca ta obejmuje uruchamianie transportu publicznego, utrzymanie dworców i przystanków oraz wspólny system taryfowy. Podstawową metodą ustalania wysokości udziału w kosztach uruchamiania pociągów SKM Warszawa jest wycena usługi na podstawie sumy pockm zaplanowanych w rozkładach jazdy linii tego przewoźnika między określonymi stacjami kolejowymi oraz stawki jednostkowej za pockm ustalanej $\mathrm{w}$ porozumieniu [6].

\section{Proponowane rozwiązania prawno- -organizacyjne}

Przede wszystkim, należy odróżnić koncepcje kolei aglomeracyjnych, realizowanych, jako kolejne oferty handlowe przewoźników regionalnych od kolejowych przewoźników aglomeracyjnych, wyspecjalizowanych w wykonywaniu tego typu usług (SKM Warszawa) $\mathrm{z}$ wyodrębnioną $\mathrm{w}$ tym celu własną infrastrukturą (PKP SKM, WKD). Ze względów finansowych i organizacyjnych, w Polsce dominuje rozwój (tworzonych przez organizatora regionalnego - marszałka) kolejnych ofert handlowych dla aglomeracji rozwój jest oparty na modelu „commuter rail”. W sytuacji, kiedy przewoźnik kolejowy nie jest własnością samorządu miejskiego, na poziom przewozów aglomeracyjnych musi wkroczyć marszałek województwa, ze swoim przewoźnikiem regionalnym. Kompetencje marszałków województw obejmują jednak or- ganizację innych rodzajów kolejowych przewozów pasażerskich, co skutkuje choćby tym, że tabor nabywany przez samorząd województwa jest, co do zasady projektowany do innych potrzeb przewozowych niż aglomeracyjne [26]. Tym samym, Marszałek nie jest w stanie na jednakowym poziomie obsłużyć jednocześnie potrzeb regionalnych i aglomeracyjnych. Wybierając system generujący niższy deficyt w przewozach (tj. system aglomeracyjny), niejako skazuje na wygaszenie system przewozów regionalnych, za którym sam ustawowo odpowiada.

Rozwój systemów przewozów aglomeracyjnych w Polsce, w takiej czy innej formie, pokazuje że pomimo braku krajowych przepisów definiujących przewozy aglomeracyjne oraz systemowego sposobu ich organizacji i finansowania, JST podejmują ryzyko angażowania się $\mathrm{w}$ budowę systemów masowych przewozów pasażerskich w obszarach funkcjonalnych miast wojewódzkich. Poza przywołanymi przykładami, należy wskazać również na następujące projekty systemów kolei aglomeracyjnych (o różnym charakterze), których realizacja postępuje w Polsce: Pomorska Kolej Metropolitalna w Trójmieście, Szczecińska Kolej Metropolitalna w Szczecinie, Podkarpacka Kolej Aglomeracyjna w Rzeszowie, Wrocławska Kolej Metropolitalna we Wrocławiu, Łódzka Kolej Aglomeracyjna w Łodzi, BiT City w Bydgoszczy i Toruniu lub Kolej Metropolitalna na terenie Górnośląsko-Zagłębiowskiej Metropolii. W niektórych przypadkach (np.: Szczecińska Kolej Metropolitalna) do ogólnodostępnej infrastruktury PKP PLK S.A. dobudowywane są dodatkowe pary torów przeznaczane do obsługi ruchu aglomeracyjnego, wykonywanego pociągami operatora regionalnego. Z kolei projekt Pomorskiej Kolei Metropolitalnej S.A. obejmuje budowę przez tego zarządcę nowej infrastruktury kolejowej na terenie aglomeracji trójmiejskiej w celu udostępnienia jej przewoźnikom kolejowym, w tym spółce PKP SKM, wykonującym przewozy zgodnie z własnymi taryfami.

Działania JST wynikają nie tylko $\mathrm{z}$ demografii, procesów suburbanizacji, kongestii, ale również z konieczności sprostania wyzwaniom związanym $\mathrm{z}$ dostosowaniem transportu pasażerskiego do priorytetów klimatycznych UE [2]. Tym niemniej, JST radzą sobie pomimo odpowiednich instrumentów organizacyjno-finansowych, a nie $d z i e ̨ k i$ nim. Konsekwencją niedoskonałości krajowych regulacji w tym obszarze jest jednak zwiększenie ryzyka procesu organizacji tego rodzaju przewozów oraz zmniejszenie jego efektywności. Z tego powodu, celowe byłoby rozważenie przez

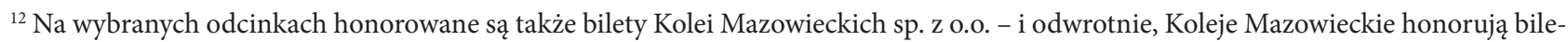
ty na pociągi SKM Warszawa. Istnieje także wspólny bilet ZTM - KM - WKD.
} 
właściwe organy wdrożenia regulacji adekwatnych do występujących potrzeb w tym obszarze. Celem takiego działania powinno być wypracowanie i wdrożenie rozwiązań w co najmniej trzech obszarach:

1) modelu finansowania jednolitego sytemu taryfowego (w tym tzw. wspólnego biletu),

2) formy organizacyjno-prawnej współdziałania organizatorów transportu publicznego dotyczących organizacji i realizacji przewozów aglomeracyjnych,

3) wsparcia finansowego $z$ budżetu państwa tworzenia przewozów aglomeracyjnych przez premiowanie współdziałania i efektywności jego organizatorów.

Zakładając neutralność dla budżetu państwa proponowanych zmian, rekomendacje wymagałyby odejścia od klasycznego przypisania kosztu usługi transportowej do konkretnego dokumentu księgowego, jakim w tym wypadku jest bilet kolejowy. Zamiast tego, podstawą rozliczenia kolejowej usługi przewozowej, wykonanej na podstawie biletu kolejowego zintegrowanego z biletami komunikacji miejskiej, powinno być osiągnięcie określonych efektów przewozowych. Taki sposób podejścia w sektorze kolejowym nie jest niczym nowym. Zgodnie $\mathrm{z}$ art. 38a ust. 1 ustawy z dnia 28 marca 2003 r. o transporcie kolejowym [11], w ramach tzw. kontraktu utrzymaniowego [48], finansowana jest przez państwo część kosztów PKP PLK S.A. niebędących kosztami bezpośredniego dostępu do infrastruktury. Kontrakt wieloletni na jej utrzymanie jest rozliczany na podstawie wskaźników, a nie kosztów opartych na konkretnych dokumentach księgowych. Sam kontrakt określa zakres wydatków, jakie kwalifikują się do sfinansowania przez stronę publiczną. W celu zabezpieczenia interesów budżetu państwa, poprawność wydatkowania środków w każdym roku budżetowym weryfikowana jest przez biegłego rewidenta. System ten zastąpił poprzedni sposób podejścia oparty na fakturach potwierdzających poniesiony wydatek, ponieważ nie wszystkie koszty mogły być $\mathrm{w}$ ten sposób rozliczone biorąc pod uwagę, że poziom dofinasowania koszów operacyjnych PKP PLK S.A. przekracza 50\% całości. Sposób określania kosztów kwalifikowanych do ich sfinansowania przez budżet państwa jest ustalany $\mathrm{w}$ umowie na realizację programu wieloletniego „Pomoc w zakresie finansowania kosztów zarządzania infrastrukturą kolejową, w tym jej utrzymania i remontów do 2023 roku".

Przyjęcie wskaźnikowego sposobu rozliczania przejazdów zrealizowanych na podstawie zintegrowanego biletu, powinno opierać się na dwóch podstawo- wych parametrach: liczbie przewiezionych pasażerów oraz cenie tej usługi (zamiast wartości biletu kolejowego), z uwzględnieniem ulg ustawowych. $\mathrm{W}$ ten sposób, aglomeracje miejskie byłyby finansowo zainteresowane we wdrożeniu zintegrowanej taryfy, ponieważ wraz ze wzrostem liczby pasażerów przewiezionych na jej podstawie, rosłaby rekompensata, jaką uzyskiwałyby z tego tytułu ze strony budżetu państwa (z uwzględnieniem limitów na to przewidzianych). Dlatego nie byłoby to dodatkowe źródło rekompensaty dla JST. Byłby to dotychczasowy zwrot za ulgi ustawowe, finansowany $z$ istniejącego źródła, lecz nieco odmiennie rozliczany. Wymagałoby to jednak zmiany w przepisach prawa. Zgodnie z $\$ 3$ ust. 1 Rozporządzenia Ministra Finansów z dnia 17 września 2010 r. w sprawie dotacji przedmiotowej do krajowych przewozów pasażerskich: (...) podstawę obliczenia należnej dotacji stanowi wartość utraconych wplywów taryfowych $z$ tytutu stosowania ulg przejazdowych, przy zrealizowanej, udokumentowanej $i$ zewidencjonowanej sprzedaży biletów (...) [7]. Z obecnego brzmienia przepisu wyni$\mathrm{ka}$, iż muszą to być bilety wystawione przez danego przewoźnika i to na usługę przez niego świadczoną, co przy wspólnym bilecie jest niemożliwe.

Przyjęty sposób liczenia wysokości rekompensaty powinien być maksymalnie prosty i łatwy do wyliczenia (w aspekcie dostępności danych). Współczynnik osób posiadających określone ulgi ustawowe mógłby decydować o tym, ile usług transportowych (w ujęciu procentowym) będzie uznanych za wykonane na rzecz osób z uprawnieniami do danej ulgi. Tym samym, byłby podstawą do uzyskania rekompensaty za utracone przychody w przewozach aglomeracyjnych na podstawie wspólnego biletu. Wskaźnik ten mógłby być albo z góry określony przez władze publiczne, albo każdorazowo wyliczany na podstawie struktury sprzedaży biletów danego organizatora $w$ ramach wspólnego biletu, niezależnie od rodzaju usługi przewozowej (kolej, tramwaje, autobusy i itp.).

W efekcie, ustawodawca mógłby nawet niejako wymusić na organizatorach szczebla JST integrację taryf kolejowo-miejskich (aglomeracyjnych), ponieważ tylko zintegrowane oferty, uwzględniające ulgi ustawowe, kwalifikowałyby się do rozliczenia $\mathrm{z}$ budżetem państwa. Nie chodzi przy tym o to, aby finansować $\mathrm{z}$ budżetu państwa wyłącznie ulgi w ramach taryf zintegrowanych, a jedynie o fakt, że oferty przewoźników i organizatorów kolejowych przewozów pasażerskich, którzy zintegrują swoje taryfy z komunikacją miejską w aglomeracjach, kwalifikowałyby się do takiego finansowania ${ }^{13}$. Wymaga to jednak

\footnotetext{
${ }^{13} \mathrm{Z}$ zachowaniem możliwości również dotychczasowego rozliczania należności za przychody utracone z tytułu obsługi pasażerów korzystających tylko z niezintegrowanych ofert kolejowych.
} 
zaangażowania ustawodawcy, aby wspólny bilet był faktycznie dostępnym i możliwym do wykorzystania rozwiązaniem systemowym, a nie jedynie namiastką, tworzoną na zasadzie doraźnej.

Dla takiego rozwiązania, partnerem budżetu państwa powinna być struktura w postaci aglomeracyjnego związku transportowego, jako nowa forma organizacji transportu publicznego na terenach miejskich obszarów funkcjonalnych. Związek mógłby obejmować JST wszystkich szczebli wokół danej aglomeracji. Posiadałby osobowość prawną i mógłby przejmować część lub całość kompetencji w zakresie planowania i organizacji wszystkich gałęzi transportu publicznego swoich członków. Wzorem dla tego rodzaju rozwiązań prawnych mogłyby zostać istniejące w systemie prawnym związki gminne i powiatowe. Odnosząc te propozycje do rozwiązań zagranicznych, należy podkreślić, że polegają one głównie na funkcjonowaniu spółek kapitałowych (wspomniany VBB, ale również czeski KODIS, spółka z o.o., zarządzający zintegrowanym systemem sprzedaży i rozliczania biletów ODIS w Kraju Morawsko-Śląskim, odpowiednikiem polskiego województwa [41] lub związków samorządowych (niemiecki Verkehrsverbund Rhein-Ruhr VRR, tj. Związek Komunikacyjny Renu-Ruhry zrzeszający szczebel powiatowy) [63], ale też na zasadzie powierzania organizatorom należącym do innych samorządów obowiązku organizacji transportu publicznego na własnym obszarze (np. czeski ROPID, Regionalny Organizator Praskiego Transportu Zintegrowanego, organizujący usługi przewozowe w Pradze oraz na zlecenie gmin, powiatów i władz Kraju Środkowoczeskiego, które powierzyły mu świadczenie usług transportowych) [55]. Rozwiązaniem zbliżonym do proponowanego jest natomiast mechanizm prawny wykorzystany np. we francuskiej aglomeracji Lille, w której organizacja transportu należy do Europejskiego Związku Metropolitalnego Lille (Métropole Européenne de Lille, MEL). Jest to organizator PTZ, który utworzono z mocy prawa w $1966 \mathrm{r}$. przez miasto Lille oraz samorządy wokół niego, w północnej części Francji [46].

Nowa regulacja powinna być wprowadzona do ustawy PTZ. Do jej obligatoryjnych kompetencji należałaby organizacja przewozów kolejowych, do czego nie jest zobowiązany związek metropolitalny. Powinna zawierać zasady modelu finansowania jednolitego sytemu taryfowego i wspólnego biletu. Alternatywnym rozwiązaniem jest zmiana ustawy PTZ przez zobowiązanie istniejącej formy związku metropolitalnego do organizacji i finansowania przewozów kole- jowych, zintegrowanych na obszarze całej aglomeracji z komunikacją miejską i podmiejską, z określeniem źródła tego finansowania (w tym wcześniej wskazanego, pochodzącego $\mathrm{z}$ budżetu państwa na refinansowanie ulg ustawowych).

Wprowadzenie aglomeracyjnego związku transportowego powinno wiązać się z wdrożeniem przepisów dotyczących sposobu finansowania przewozów aglomeracyjnych przez gminy i powiaty będące jego członkami, a obecnie nieposiadające obowiązku finansowania tego rodzaju usług ${ }^{14}$. Zmianom ustawowym powinny towarzyszyć wspomniane zmiany aktów wykonawczych, umożliwiające wskaźnikowe rozliczanie wspólnego biletu.

Rozwiązania regulujące partycypację JST wszystkich szczebli w organizacji przewozów aglomeracyjnych powinny być stymulowane wsparciem $\mathrm{z}$ budżetu centralnego np. przez zwiększenie udziału tych podmiotów w podatku od osób prawnych, który historycznie stanowi źródło finansowania przewozów kolejowych na szczeblu samorządu terytorialnego. $\mathrm{W}$ przeciwnym razie, procesy demograficzne oraz brak stymulacji finansowej doprowadzą do kolejnej zapaści segmentu przewozów regionalnych, kanibalizowanych finansowo przez znacznie bardziej efektywne przewozy aglomeracyjne.

\section{Literatura}

\section{Materiały źródłowe}

1. Federal Transit Administration U.S. Department of Transportation, 2013 Reporting Year National Transit Database Glossary, September 2013.

2. Komunikat Komisji do Parlamentu Europejskiego, Rady Europejskiej, Rady, Komitetu Ekonomiczno - Społecznego i Komitetu Regionów, Europejski Zielony Ład, Bruksela, dnia 11.12.2019 r., COM (2019)640 final.

3. Ministerstwo Funduszy i Polityki Regionalnej, Szczególowy opis osi priorytetowych Programu Operacyjnego Infrastruktura i Srodowisko 2014-2020, Warszawa, 19 listopada $2020 \mathrm{r}$.

4. Najwyższa Izba Kontroli, Informacja o wynikach kontroli „Realizacja zadań publicznych przez spótki tworzone przez jednostki samorzadu terytorialnego", Warszawa 2014.

5. Plan zrównoważonego rozwoju transportu zbiorowego dla m.st. Warszawy z uwzględnieniem publicznego transportu zbiorowego organizowanego na podstawie porozumień $\mathrm{z}$ gminami sąsiadu-

\footnotetext{
${ }^{14}$ Obecnie, z problemem poradzono sobie tylko w projekcie PKM: jest ona finansowana ze środków: Marszałka Wielkopolskiego na poziomie $85 \%$ kosztów realizacji przewozów aglomeracyjnych, gmin $10-15 \%$, a powiatów 3,5-6,6\% [21].
} 
jącymi. Załącznik do uchwały Rady m.st. Warszawy Nr XI/198/2015 z dn. 7 maja 2015 r.

6. Porozumienie nr GK.031.2.2014 zawarte między Miastem Stołecznym Warszawa a Gminą Legionowo w dniu 2014-02-10 (Dz.U. Województwa Mazowieckiego dnia 10 lipca 2014 r. poz. 6679).

7. Rozporządzenie Ministra Finansów z dnia 17 września 2010 r. w sprawie dotacji przedmiotowej do krajowych przewozów pasażerskich (Dz.U z 2020, poz. 1265).

8. Uchwała nr 105/2019 Rady Ministrów z dnia 24 września 2019 r. w sprawie przyjęcia Strategii Zrównoważonego Rozwoju Transportu do 2030 roku (Monitor Polski, 2019, poz. 1054, s. 75).

9. Uchwała Nr 239/2011 Rady Ministrów z dnia 13 grudnia 2011 r. w sprawie przyjęcia Koncepcji Przestrzennego Zagospodarowania Kraju 2030 (Monitor Polski, 2012 poz. 252).

10. Ustawa $\mathrm{z}$ dnia 9 marca 2017 r. o związku metropolitalnym w województwie śląskim (Dz.U. z 2017 r., poz. 730).

11. Ustawa $\mathrm{z}$ dnia 28 marca 2003 r. o transporcie kolejowym (Dz.U. z 2020 r. poz. 1043, 1378, 1778, z 2021 r. poz. 780, 784).

12. Ustawa $\mathrm{z}$ dnia 25 czerwca 2009 r. o zmianie ustawy o autostradach płatnych oraz o Krajowym Funduszu Drogowym oraz o zmianie niektórych innych ustaw (Dz.U. Nr 116, poz. 975).

13. Ustawa $z$ dnia 25 września 1981 r. o przedsiębiorstwach państwowych (Dz.U. z 2020 r., poz. 1644).

14. Ustawa z dnia 9 października 2015 r. o związkach metropolitalnych (Dz.U. z dnia 18 listopada 2015 r. poz. 1890).

15. Ustawa $\mathrm{z}$ dnia 15 listopada 1984 r. Prawo przewozowe (Dz.U. z 2020 r. poz. 8).

16. Ustawa $z$ dnia 16 grudnia 2010 r. o publicznym transporcie zbiorowym (Dz.U. 2020 poz. 1944).

17. Wehmeier S. (ed.): Oxford Advanced Learner's Dictionary of Current English, Oxford 2003.

18.Załącznik do uchwały Nr 425/19 Zarządu Województwa Małopolskiego $\mathrm{z}$ dnia 22 marca 2019 r. dotyczace porozumienia w sprawie współpracy w zakresie rozwoju transportu kolejowego na terenie województwa małopolskiego poprzez budowę nowej linii kolejowej łączącej Miasto Kraków z Gminą Myślenice.

19. Załącznik do Uchwały Nr 744/12 Zarządu Województwa Małopolskiego z dnia 28 czerwca 2012 r. „Porozumienie wstępne $\mathrm{w}$ przedmiocie wyrażenia woli współdziałania i współpracy między Województwem Małopolskim a lokalnymi jednostkami samorządu terytorialnego przy przygotowaniu i realizacji przedsięwzięcia inwestycyjnego z zakresu transportu publicznego polegającego na zagospodarowaniu węzłów komunikacyjnych zlokalizowanych w Obszarze Obsługiwanym przez Szybką Kolej Aglomeracyjną".

\section{Opracowania monograficzne i prezentacje}

20. Ciastoń A.: Koleje aglomeracyjne $i$ regionalne w Europie, TTS Technika Transportu Szynowego, nr 10/2007.

21. Frąckowiak B.: Pełnomocnik Zarządu Stowarzyszenia Metropolia Poznań ds. PKM, Prezentacja pt.: Poznańska Kolej Metropolitalna. Komplementarność, jako klucz do sukcesu, wygłoszona w dniu 25.05.2021.

22. Kajdanek K.: Pomiędzy miastem a wsia. Suburbanizacja na przykładzie osiedli podmiejskich Wrocławia, Kraków 2011.

23. Kociuba D.: Metropolises and metropolitan areas in Poland: problems of classification and delimitation, 7-th International Conference of $\mathrm{PhD}$ Students at University of Miskolc, Hungary, M. Dóbroka, P. Bikfalvi (eds.), Volume: Natural Science, p. 81-86, September 2010.

24. Kołoś A., Trzepacz P.: Transport, a metropolitalność - przykład Berlina, Instytut Geografii i Gospodarki Przestrzennej Uniwersytetu Jagiellońskiego, Prace Geograficzne zeszyt 125, Kraków 2010.

25. Koźlak A.: Kolej aglomeracyjna, jako podstawa systemu komunikacyjnego obszarów metropolitalnych w Polsce [w:] M. Michałowska (red.), Współczesne uwarunkowania rozwoju transportu $w$ regionie, Katowice 2013.

26. Lalik M.: Tabor szynowy do przewozów aglomeracyjnych, Centrum Naukowo-Techniczne Kolejnictwa, Problemy Kolejnictwa - Zeszyt 148, Warszawa 2009.

27. Lisowski A., Grochowski M.: Procesy suburbanizacji. Uwarunkowania, formy i konsekwencje [w:] Ekspertyzy do koncepcji przestrzennego zagospodarowania kraju 2008-2033, T. 1, MRR, Warszawa 2008.

28. Mandri-Perrot A.: Private Sector Participation in Light Rail-Light Metro Transit Initiatives, The World Bank, Washington 2010.

29. Mazur B.: Finansowanie ulg $w$ przewozach pasażerskich - wybrane zagadnienia, prezentacja wygłoszona w trakcie IV. Ogólnopolskiej Konferencji Naukowej „Konsument na rynku kolejowych przywozów pasażerskich", 26.04.2017 Łódź.

30. Raczyńska-Buława E.: Systemy kolei aglomeracyjnych $w$ Polsce, TTS - Technika Transportu Szynowego 7-8/2015.

31. Romanowski M.: Cel spółki i charakter prawny umowy spótki, Studia Prawa Prywatnego 03/2015.

32.Śleszyński P.: Delimitacja Miejskich Obszarów Funkcjonalnych stolic województw, Przegląd Geograficzny, Tom 85, zeszyt 2, Warszawa 2013.

33. The World Bank, Removing Barriers to Public Transport Integration in Poland. Key Directions of Change, Washington DC 2016.

34.Żurkowski A.: Intermodalne uwarunkowania rytmizacji przewozów pasażerskich, Logistyka 3/2012. 


\section{Źródła internetowe:}

35.http://bustramwajkolej.pl/ [dostęp 4.07.2021].

36. https://dopiewo.pl/aktualnosci/2017-11-18/samorzady-wypracowaly-model-finansowania-pkm [dostęp 19.07.2021].

37. https://gazeta.myslenice.pl/z-krakowa-do-myslenickoleja-jest-porozumienie, [dostęp 11.08.2021].

38.https://www.mamnewsa.pl/gospodarka/ szybka-kolej-do-krakowa-jest-porozumieniesamorzadowcow [dostęp 11.08.2021].

39. Oficjalna strona internetowa Berlińskiego Przedsiębiorstwa Transportowego: https://www.bvg.de/en/ Travel-information/Local-rail [dostęp 21.11.2020].

40. Oficjalna strona internetowa InnoBaltica Sp. z o.o. http://www.innobaltica.pl/1_18_o-ulgach.html [dostęp 07.12.2020].

41. Oficjalna strona internetowa KODIS: https://www. kodis.cz/en/dopravni-infocentra/about-us/87/ about-us.html [dostęp 10.07.2021].

42. Oficjalna strona internetowa Kolei Małopolskich: https://malopolskiekoleje.pl/index.php/podroz/37-bilety-honorowane [dostęp 25.07.2021].

43. Oficjalna strona internetowa Kolei Wielkopolskich sp. z o.o.: https://koleje-wielkopolskie.com.pl/dlapasazera/honorowanie-biletow/ [dostęp 4.07.2021].

44. Oficjalna strona internetowa Kolei Wielkopolskich sp. z o.o.: https://koleje-wielkopolskie.com. pl/dla-pasazera/oferty-specjalne/, zakładka bustramwajkolej.pl [dostęp 4.07.2021].

45. Oficjalna strona Komisji Europejskiej https://ec.europa.eu/regional_policy/en/policy/what/glossary/p/partnership-agreement [dostęp 07.12.2020].

46. Oficjalna strona internetowa MEL: https://www. lillemetropole.fr/en/your-daily/your-daily [dostęp 10.07.2021].

47. Oficjalna strona internetowa Ministerstwa Funduszy i Polityki Regionalnej: https://www.funduszeeuropejskie.gov.pl/strony/o-funduszach/zasadydzialania-funduszy/zintegrowane-inwestycje-terytorialne/ [dostep 04.12.2020].

48. Oficjalna strona internetowa Ministerstwa Infrastruktury https://www.gov.pl/web/infrastruktura/pomoc-w-zakresie-finansowania-kosztowzarzadzania-infrastruktura-kolejowa-w-tym-jejutrzymania-i-remontow-do-2023-roku [dostęp 25.07.2021].

49. Oficjalna strona (archiwalna) Ministerstwa Inwestycji i Rozwoju: https://archiwum.miir.gov.pl/ strony/zadania/polityka-rozwoju-kraju/zarzadzanie-rozwojem-kraju/koncepcja-przestrzennegozagospodarowania-kraju/ [dostęp 02.12.2020].
50. Oficjalna strona (archiwalna) Ministerstwa Inwestycji i Rozwoju: https://miir.bip.gov.pl/strategierozwoj-regionalny/17847_strategie.html [dostęp 02.12.2020].

51. Oficjalna strona internetowa National Rail: https://ojp.nationalrail.co.uk/service/timesandfares/KGX/HAY/021220/2230/dep\#outwardJump [dostęp 02.12.2020].

52. Oficjalna strona internetowa POLREGIO sp. z o.o.: https://polregio.pl/pl/dla-podroznych/informacje/wielkopolskie-przyspiesza-z-polregio/ [dostęp w dniu 4.07.2021].

53. Oficjalna strona internetowa Poznańskiej Kolei Metropolitalnej http://www.kolej.metropoliapoznan.pl/, dostęp w dniu 4.07.2021.

54. Oficjalna strona internetowa PV: https://www. pv.lv/en/about-us/ [dostęp 24.11.2020].

55. Oficjalna strona internetowa ROPID: https://pid.cz/oorganizaci/o-organizaci-ropid/ [dostęp 10.07.2021].

56. Oficjalna strona internetowa S-Bahn Berlin GmbH (spółki-córki DB Regio AG) https://sbahn. berlin/en/tickets/the-vbb-fare-explained/ [dostęp 24.11.2020].

57. Oficjalna strona internetowa Stowarzyszenia Integracji Stołecznej Komunikacji http://siskom.waw. pl/kp-parkingi.htm [dostęp 02.12.2020].

58. Oficjalna strona internetowa Stowarzyszenia Metropolia Poznań: http://www.metropoliapoznan. pl/strona,4,poznanska_kolej_metropolitalna.html [dostęp 4.07.2021].

59. Oficjalna strona internetowa Stowarzyszenia Metropolia Poznań: http://metropoliapoznan.pl/strona,17,rada_metropolii.html [dostęp 4.07.2021]. Oficjalna strona internetowa Stowarzyszenia na rzecz Niepełnosprawnych SPES: https://www. spes.org.pl/twoje-prawa/transport-i-ulgi-wprzejazdach [dostęp w dniu 07.12.2020].

60. Oficjalna strona internetowa Transport for London https://tfl.gov.uk/fares/how-to-pay-and-where-tobuy-tickets-and-oyster/pay-as-you-go/oyster-payas-you-go?intcmp $=55536$ [dostęp 21.11.2021].

61. Oficjalna strona internetowa Urzędu Transportu Kolejowego (UTK): https://www.utk. gov.pl/pl/pasazerowie/kolejowe-faq/przejazdybezplatne/14418,Przejazdy-bezplatne-i-ulgowe. html [dostęp 07.12.2020].

62. Oficjalna strona internetowa VRR: https://www. vrr.de/en/vrr/an-overview/ [dostęp 10.07.2021].

63. Oficjalna strona internetowa Vy: https://www.vy.no/en/traffic-and-routes/stations-and-networkmaps [dostęp 24.11.2020]. 